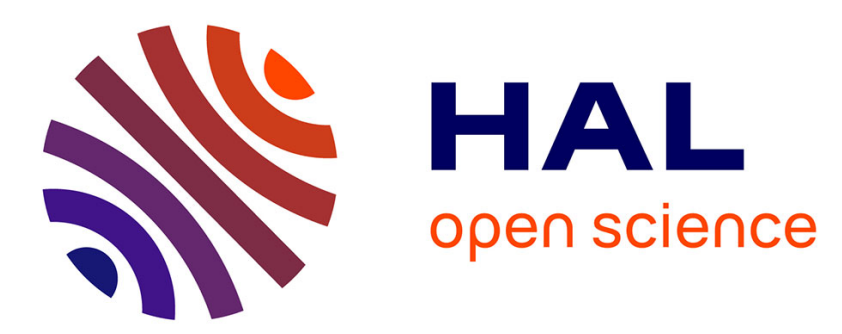

\title{
Unexpectedly low organic matter content in Cariaco Basin sediments during the Younger Dryas: Origin and implications
}

\author{
Armelle Riboulleau, Nicolas Tribovillard, François Baudin, Viviane \\ Bout-Roumazeilles, Timothy W. Lyons
}

\section{To cite this version:}

Armelle Riboulleau, Nicolas Tribovillard, François Baudin, Viviane Bout-Roumazeilles, Timothy W. Lyons. Unexpectedly low organic matter content in Cariaco Basin sediments during the Younger Dryas: Origin and implications. Comptes Rendus Géoscience, 2011, 343, pp.351-359. 10.1016/j.crte.2011.04.001 . hal-00600174

\section{HAL Id: hal-00600174 https://hal.science/hal-00600174}

Submitted on 31 Aug 2021

HAL is a multi-disciplinary open access archive for the deposit and dissemination of scientific research documents, whether they are published or not. The documents may come from teaching and research institutions in France or abroad, or from public or private research centers.
L'archive ouverte pluridisciplinaire HAL, est destinée au dépôt et à la diffusion de documents scientifiques de niveau recherche, publiés ou non, émanant des établissements d'enseignement et de recherche français ou étrangers, des laboratoires publics ou privés. 


\title{
Unexpectedly low organic matter content in Cariaco Basin sediments during the Younger Dryas: Origin and implications
}

Origine et implications de la très faible teneur en matière organique dans les sédiments du bassin de Cariaco au Dryas récent

Armelle Riboulleau ${ }^{\text {a, }}$, Nicolas Tribovillard ${ }^{\text {a }}$, François Baudin ${ }^{\text {b }}$, Viviane Bout-Roumazeilles a, Timothy W. Lyons ${ }^{\mathrm{c}}$

a FRE CNRS 3298 géosystèmes, université Lille 1, bâtiment SN5, 59655 Villeneuve d'Ascq cedex, France

b UPMC-University Paris 06 et CNRS, UMR 7193 iSTeP, 4, place Jussieu, case 117, 75252 Paris cedex 05, France

c Department of Earth Sciences, University of California, CA 92521-0423 Riverside, USA

* Corresponding author.

E-mail addresses: armelle.riboulleau@univ-lille1.fr (A. Riboulleau), nicolas.tribovillard@univ-lille1.fr (N. Tribovillard), francois.baudin@upmc.fr (F. Baudin), viviane.bout@univ-lille1.fr (V. Bout-Roumazeilles), timothyl@ucr.edu (T.W. Lyons).

Keywords: Cariaco Basin, Upwelling, Diatoms, Dinoflagellates, Geochemistry, Organic matter

Mots clés : Basin de Cariaco, Upwelling, Diatomées, Dinoflagellés, Géochimie, Matière organique

\begin{abstract}
The Cariaco Basin (offshore Venezuela), the second largest anoxic basin after the Black Sea, knew intense upwelling activity and maximum primary production during the Younger Dryas (12.9-11.5 ka cal. BP). Relatively low total organic carbon (TOC) contents are, however, observed in the sediment deposited during this interval. Previous studies have attributed these low TOC values to dilution by inorganic phases during a time of high sediment accumulation rate. The present study demonstrates that the low TOC values result primarily from a relatively reduced flux of organic matter $(\mathrm{OM})$ to the sediment and minor dilution by carbonate. Excellent preservation of the OM during this interval excludes OM degradation as a cause for low TOC values. Consistent with palynological observation and biomarker analyses, the lower relative flux of OM to the sediment is related to changes in the primary
\end{abstract}


producers, with a significant decrease in the contribution of organic-walled organisms during the Younger Dryas. These results, that highlight the need of caution when using TOC values as paleoproductivity or paleoenvironmental indicator, underline the important role of organicwalled primary producers in the organic enrichment of sediments.

\section{Résumé}

Le bassin de Cariaco (au large du Venezuela), deuxième bassin euxinique en taille après la Mer Noire, a connu une très forte activité d'upwelling et un maximum de productivité primaire au cours du Dryas récent (12,9-11,5 ka cal. BP). De faibles teneurs en carbone organique total (TOC) sont cependant observées dans les sédiments déposés au cours de cette période. Les études précédentes ont attribué ces faibles valeurs de TOC à une dilution par les phases inorganiques pendant une période de fort taux d'accumulation sédimentaire. Le présent travail démontre que les faibles valeurs de TOC résultent principalement d'une diminution relative du flux de matière organique $(\mathrm{MO})$ au sédiment et seulement d'une légè re dilution par les carbonates. La MO de cet intervalle présente un excellent état de préservation, ce qui exclut sa dégradation comme cause des faibles TOC. En accord avec les observations palynologiques et les analyses de biomarqueurs, le faible flux relatif de MO au sédiment est lié à une diminution importante de la contribution du plancton à paroi organique au cours du Dryas récent. Ces résultats, qui montrent que les valeurs de TOC doivent être utilisées comme indicateur de paléoproductivité ou de paléoenvironnement avec précaution, soulignent le rôle important des producteurs primaires à paroi organique dans l'enrichissement des sédiments en matière organique.

\section{Introduction}

The Cariaco Basin is a small tectonic depression located on the northern continental shelf of Venezuela. Its depth extends to $1400 \mathrm{~m}$, but the basin is largely separated from the Caribbean Sea by the Tortuga Bank and is only connected to the open sea by two shallow, ca. 130m deep, sills (Fig. 1). Due to seasonal upwelling, the modern Cariaco Basin has high primary productivity (520 gCorg. $\mathrm{m}^{-2} \cdot \mathrm{a}^{-1}$ on average for 1996-2002; Müller- Karger et al., 2001). The high oxygen demand induced by organic matter (OM) decay, added to weak renewal of bottom waters, led to progressive oxygen depletion of the water column (Peterson et al., 1991). Currently, the water column is euxinic below $300 \mathrm{~m}$, and the sediments are relatively organic-rich, with TOC contents generally ranging between 2 and 5\% (Daumas et al., 1978; Lyons et al., 2003; Richards, 1975). 
First studied in the 1950s, the Cariaco Basin has seen renewed interest during the last two decades because it offers one of the best low latitude paleoclimatic records of the Pleistocene-Holocene (Haug et al., 2001; Hughen et al., 1996a; Peterson et al., 1991; Peterson and Haug, 2006). Its annually laminated sediments have also yielded several studies focused on better calibration of radiocarbon dates (Hughen et al., 1998, 2004b, 2006). The Cariaco Basin is the object of a long term oceanographic study, as it represents an ideal site to better constrain the links between primary productivity, nutrient cycles and flux of OM to the sediment (Müller-Karger et al., 2001, 2010).

The sediments of the Cariaco Basin display a temporal color pattern (gray scale) that closely parallels temperature records from Greenland ice cores (Hughen et al., 1996b; Peterson et al., 2000). These color patterns are related to variation in the total organic carbon (TOC) content of the sediment, the organic-rich intervals being the darkest (Peterson et al., 2000). Compared to the Holocene, Preboreal (PB), and Bølling-Allerød (BA) intervals, lighter sediment color and lower TOC content characterize the Younger Dryas (YD) interval (Hughen et al., 1996b; Piper and Dean, 2002; Werne et al., 2000). The origin of these low TOC values during the YD remains inadequately known. Sediments of the YD are rich in biogenic opal and calcium carbonate (Piper and Dean, 2002), contributing to their light color. The accumulation rate for terrigenous debris was also very high during this interval (Peterson et al., 1995), leading several authors to invoke dilution by biogenic and/or detrital minerals as a dominant explanation for low TOC and authigenic pyrite concentrations during the YD (Dahl et al., 2004; Lyons et al., 2003; Piper and Dean, 2002; Werne et al., 2003).

In the present article, we demonstrate by routine calculations that the low TOC values of the YD are not primarily a product of dilution by biogenic materials. Consequently, other factors influencing OM accumulation in the sediments of the Cariaco Basin through time and potentially accounting for these low TOC values are discussed.

\section{Material and methods}

This study is based on sediment from core MD03-2625 of the IMAGES Program (10840.650 N, 64858.240 W, water depth $847 \mathrm{~m}$ ) recovered during the PICASSO cruise of R/V Marion Dufresne in 2003 (Laj and Shipboard Scientific Party, 2004) and Site 1002 of the Ocean Drilling Program (ODP) (10842.730 N, 65810.180 W; water depth, 893 m; Shipboard Scientific Party, 1997) drilled in 1996. Together, the two cores captured excellent records of the Holocene and Preboreal periods and the Younger Dryas and Bølling- Allerød intervals, respectively. The sediment from both cores was sampled at an average interval of "10 cm 
("200 y). Carbonate content was determined using a Bernard Calcimeter (via acid digestion). The relative error is about $2 \%$. Total organic carbon was determined by Rock- Eval pyrolysis using a Delsi Oil Show Analyzer (OSA) at the Université P. \& M. Curie (Paris 6). Specifically, pyrolysis cycle 3 was used, which is dedicated to the analysis of recent OM (Espitalié et al., 1986). Relative error for the TOC determination is 5\%.

Major elements in bulk sediment were analyzed at the Service d'analyse des roches et des minéraux of the Centre national de la recherche scientifique (Vandoeuvre-lès- Nancy, France) using ICP-AES after fusion with $\mathrm{LiBO} 2$ and $\mathrm{HNO} 3$ dissolution. Precision and accuracy are both better than $1 \%$. The biogenic silica content (opal) was calculated as follows: opal $=\mathrm{SiO}_{2}-\mathrm{Al}_{2} \mathrm{O}_{3} \#\left(\mathrm{SiO}_{2} / \mathrm{Al}_{2} \mathrm{O}_{3}\right)_{\text {detrital }}$, where $\left(\mathrm{SiO}_{2} / \mathrm{Al}_{2} \mathrm{O}_{3}\right)_{\text {detrital }}$ is the ratio of the detrital fraction of the sediment, assumed to be constant over the study interval. This assumption is reasonable given the very strong positive correlation between $\mathrm{Si}$ and $\mathrm{Al}$ in samples of Holocene age $(\mathrm{r}=0.992, \mathrm{n}=33$, not shown $)$ where no diatom silica was reported (Peterson et al., 1995; Piper and Dean, 2002). Consistent with a high abundance of clay minerals in the sediments of the Cariaco Basin (Clayton et al., 1999), most of the studied samples, including some containing diatoms, have a $\mathrm{SiO}_{2} / \mathrm{Al}_{2} \mathrm{O}_{3}$ ratio lower than the average shale value (3; Wedepohl, 1991). $\left(\mathrm{SiO}_{2} / \mathrm{Al}_{2} \mathrm{O}_{3}\right)_{\text {detrital }}$ (i.e., 2.59) was therefore taken as the minimum $\mathrm{Si} / \mathrm{Al}_{2} \mathrm{O}_{3}$ value of the studied interval. As shown on Fig. 2, the opal contents thus obtained are in good agreement with opal contents measured by Piper and Dean (2002) on nearby core PL07-39PC. The terrigenous content (Terr) in weight percentage is calculated as follows: Terr $=100-\%$ opal $-\% \mathrm{CaCO}_{3}-\%$ TOC.

Due to the different sedimentation rates in the two cores, the results are discussed in terms of sediment age. The age model used for core ODP 1002 has been described previously (Haug et al., 2001; Hughen et al., 2004a). For core MD03-2625, the age model was determined by correlating the colorimetric parameter $\mathrm{a}^{*}$, describing sediment color in the range from red to green (Laj and Shipboard Scientific Party, 2004), with gray scale data for core PL07-56PC for which a revised age model has been generated (Hughen et al., 2000). Correlation of colorimetric data has been shown to be a particularly efficient method for sediments of the Cariaco Basin (Hughen et al., 1996b). For the correlation, core PL07-56PC was preferred over ODP Site 1002 because it is located closer to core MD03- 2625 and is very well dated (Hughen et al., 2000). The software used for the correlation was AnalySeries (Paillard et al., 1996). The ages are presented as calibrated years before present (a cal. B.P.). The sedimentation rates obtained by this method range from 0.3 to $1.4 \mathrm{~mm} . \mathrm{a}^{-1}$, which are within the typical range for the Cariaco Basin (Hughen et al., 1996a; Peterson et al., 1991). 


\section{Results}

Temporal variations of TOC, $\mathrm{CaCO}_{3}$ and opal contents are presented in Fig. 2. Though less pronounced in our dataset than in other studies (Mertens et al., 2009a; Piper and Dean, 2002; Werne et al., 2000), previously noted temporal patterns are clearly recognizable. In particular, we note the relatively low TOC values during the YD (mean 2.4\%), when compared to the $\mathrm{BA}$ and $\mathrm{PB}$ with mean values of $4.1 \%$ and $3.9 \%$, respectively. Maximum TOC values are observed at the end of the PB-beginning of the Holocene. The $\mathrm{CaCO}_{3}$ content also shows a characteristic behavior during the $\mathrm{YD}$ (Fig. 2). While the $\mathrm{CaCO}_{3}$ content is approximately $20 \%$ during the $\mathrm{BA}$ and $\mathrm{PB}$, it rises to $30 \%$ during the $\mathrm{YD}$. Opal is present in the sediments of the BA to PB and disappears after the PB. Conversely to TOC and $\mathrm{CaCO}_{3}$, the opal content is not constant during the YD. Relatively low at the beginning of the YD (7\%), the opal content increases during the course of the YD to reach maximum values $(30 \%)$ at the beginning of the $\mathrm{PB}$. The TOC is also presented on a carbonate-free basis $\left(\mathrm{TOC}_{\mathrm{CF}}\right.$; Fig. 2). Similarly to $\mathrm{TOC}$ values, $\mathrm{TOC}_{\mathrm{CF}}$ values are lower during the $\mathrm{YD}$ interval compared to the BA and PB (Fig. 2).

In the studied interval, hydrogen index (HI) values show moderate variations between 250 and $450 \mathrm{mg}$ hydrocarbons (HC)/g TOC. Despite slight discrepancies observed between the two studied cores, the values generally agree with those previously obtained by Aycard (2004) on Hole ODP 1002 C (Fig. 2). The BA and Holocene intervals show similar and relatively constant values around $340 \mathrm{mg} \mathrm{HC/g}$ TOC. The YD begins with lower values that increase during the course of the YD, to reach a maximum at the YD-PB transition. Values then progressively decrease to Holocene values during the course of the PB.

Fig. 2 also shows the same dataset from core PL07-39PC (Piper and Dean, 2002; data courtesy Larry Peterson). These results are very similar to those obtained for core MD032625. Slight differences are seen between core PL07-39PC and ODP site 1002, the latter showing lower biogenic mineral content during the BA (Fig. 2). The dissimilarity probably reflects the different location of the sites relative to the upwelling center (Fig. 1). Recent modeling (Lane-Serff and Pearce, 2009) showed that due to lower sea level, the Cariaco upwelling cell was smaller and shifted to the east during the BA, so that ODP Site 1002 was relatively distant from the upwelling center compared to the sites of core PL07-39PC and MD03-2625 (Fig. 1). It is worth noticing the very similar TOC patterns for both cores despite the relatively different biogenic mineral contents. 


\section{Discussion}

\subsection{Role of dilution}

The TOC content shows no correlation with opal content, while a slight positive tendency $(\mathrm{r}=0.53, \mathrm{n}=35)$ and a negative correlation $(\mathrm{r}=-0.76, \mathrm{n}=35)$ are observed with the terrigenous and $\mathrm{CaCO}_{3}$ contents, respectively (Fig. 3). From these observations, the carbonate content, that varies antithetically to TOC content through the BAYD- PB intervals (Fig. 2), appears as a diluting phase for the OM during the YD. The study of Mertens et al. (2009a) allowed identify the origin of the generally higher carbonate content of the sediment during the YD compared to $\mathrm{PB}$ and $\mathrm{BA}$ : from the lower relative abundance of pteropods in the sediment ("pteropod ratio"), it appears that the Cariaco water column was more aggressive towards carbonates during the $\mathrm{BA}$ and $\mathrm{PB}$ than during the $\mathrm{YD}$. The higher $\mathrm{CaCO}_{3}$ content of the sediment during the YD therefore reflects a lower dissolution of carbonates and more alkaline conditions in the water column. TOC values calculated on a carbonate-free basis (TOCCF) allowing one to overcome dissolution problems, however remain low during the YD compared to the PB and BA intervals (Fig. 2). From this observation, it appears that if carbonate dilution contributes to the low TOC values observed during the YD, it is not the major cause.

\subsection{A reduced organic flux during the Younger Dryas}

Mass accumulation rates(MAR) could not be determined for core MD03-2625, but a sufficiently robust age model allowed MAR calculations for core PL07-39PC (Piper and Dean, 2002, as updated by L. Peterson, Pers. Comm.). These data show that, during the YD, the flux of all sediment fractions increased, including the flux of OM(Fig. 5; Table 1). This observation led several authors to conclude that the YD was the period of highest primary productivity in the basin over the last 14.7 ka (Peterson et al., 1995; Piper and Dean, 2002; Werne et al., 2000). Careful examination of MAR values, however, reveals that the increase in MAR for TOC during the YD was muted compared to the other sediment components (Fig. 5; Table 1).

Modern trap studies show that mineral ballasting has a strong effect on the OM flux to the sediment in the Cariaco Basin, such that the TOC and total mineral fluxes in the water column are strongly correlated (Thunell et al., 2007; Fig. 4A). Consistent with sediment trap data, a positive correlation is observed between MAR values for TOC and total mineral inputs in core PL07-39 PC (Fig. 4A). The slope of this correlation is, however, lower than for present-day sediment traps (Fig. 4A). This lower slope might be related to the location of core 
PL07-39PC on the margins of the upwelling cell, while the sediment traps were located in the center of the cell (Fig. 1). However, this lower slope must also point to OM degradation within the sediment after deposition (Goni et al., 2003). Sediments deposited during the YD yield a third correlation line, with a slope that is lower than for the rest of core PL07-39PC (Fig. 4A). This lower slope points to a decreased Corg/mineral flux ratio during the YD compared to the rest of the interglacial. This reduced Corg/mineral flux ratio partly results from the better preservation of carbonates during the $\mathrm{YD}$, so the same data excluding the $\mathrm{CaCO}_{3} \mathrm{MAR}$ are shown on Fig. 4B. Though there is more scatter, Fig. 4B also shows the decreased Corg/mineral flux ratio during the YD compared to the rest of the interglacial. From these data, it appears that during the YD the flux of OM to the sediment, though high, was lower than expected.

\subsection{Organic matter degradation}

A first explanation to the reduction of the flux of OM relatively to the mineral flux during the YD is that $\mathrm{OM}$ was more efficiently degraded, either in the water column or within the sediment. In the sediments of the Cariaco Basin where OM is mainly of autochthonous origin (Combaz and Pelet, 1978; Dahl et al., 2004; Wakeham, 1990; Werne et al., 2000), HI values will preferentially reflect the degree of degradation of the OM (Espitalié et al., 1986). HI values observed in the studied interval are in the range of moderately well-preserved marine OM (Type II), consistent with the fact that despite anoxic conditions, OM is degraded in the water column (Thunell et al., 2000). Increased OM degradation during the YD should be indicated by a marked decrease of HI values. Compared to the BA, no particular decrease of HI values characterizes the YD, indicating a similar degree of preservation/ degradation than during the BA. The slight increase in HI values in the course of the YD and maximum $\mathrm{HI}$ values at the beginning of the $\mathrm{PB}$, however, could indicate better preservation of $\mathrm{OM}$ during this interval. Recent palynological data (Mertens et al., 2009b) also support this interpretation: the high abundance of degradation-sensitive dinoflagellate cysts in the sediments deposited during the YD and the beginning of the PB indicates a low degree of OM degradation during these intervals. Increased degradation of dinocycts is observed during the BA, PB and Middle Holocene (Mertens et al., 2009b). Both palynological and geochemical data indicate that the low TOC values observed during the YD are not related to OM degradation.

\subsection{Source organisms and Corg/mineral flux ratios}


In a basin where the terrigenous flux (including its terrigenous OM content) is considered as constant, changes of the Corg/mineral flux ratio will directly result from changes in surface producers: organic-walled organisms (i.e. those that do not have mineralized tissues, mainly corresponding to dinoflagellates, green algae, cyanobacteria and bacteria) mostly export OM from surface waters and therefore have high Corg/mineral export ratios; conversely, carbonate plankton and diatoms export a mineral test in addition to $\mathrm{OM}$, and therefore have lower Corg/mineral export ratios. All other things being equal, a change in surface producers from dinoflagellate-dominated to diatom-dominated should lead to a decreased OM content in the sediment, a mechanism that Tyson (1995) termed "planktonic autodilution". This simple scheme, however, can be complicated by selective degradations or dissolutions occurring in the water column. In the Cariaco Basin, diatoms are dominant during periods of upwelling, while cyanobacteria and dinoflagellates dominate during non upwelling seasons (Ferraz-Reyes, 1983). In the sediment traps data from the CARIACO time series (Thunell et al., 2007), the samples with the highest proportion of OM, and therefore the highest Corg/mineral ratio, rather show a low proportion of opal, suggesting that this OM mostly derives from cyanobacteria and dinoflagellates.

From these observations, the decreased Corg/mineral flux ratio observed during the YD interval can be explained by a relative decrease of the contribution from organic walled organisms compared to diatoms. The recent palynological study performed by Mertens et al. (2009b) gives support to this hypothesis. Despite very good preservation, the concentration and MAR of dinoflagellate cysts markedly decrease during the YD (Mertens et al., 2009b). Conversely, the PB is marked by an increase in cyst concentration, despite a lower preservation of very sensitive cysts (Mertens et al., 2009b). Keeping in mind the fact that cysts in the sediment represent a biased picture of the dinoflagellate biomass that existed in the water column (Head, 1996; Zonneveld et al., 2007), the palynological data tend to indicate a decreased dinoflagellates productivity during the YD followed by an important increase during the PB (Mertens et al., 2009b; also see Zonneveld et al., 2007). From a high-resolution biomarker study, Dahl et al. (2004) also concluded to a marked decrease of dinoflagellates compared to diatoms during the $\mathrm{YD}$, followed by a marked increase at the transition to the PB. Therefore, the marked decrease in TOC values during the YD is to be related to the important decrease in dinoflagellates proportion. In addition, it can be observed that compared to the BA, the PB shows a high increase in dinoflagellate cyst abundance (Mertens et al., 2009b) and in dinoflagellate biomarkers (Dahl et al., 2004), as well as by TOC values that also are generally higher than the BA. From these observations, organic-walled organisms and 
in particular dinoflagellates appear as an important factor controlling the TOC content of the sediments of the Cariaco Basin.

\subsection{Implications}

The contribution from organic-walled organisms to total OM can be simply modelled using MAR data from core PL07-39PC and estimating the Corg/mineral ratio of the different sediment fractions (Fig. 5; Supplementary material). The Corg/mineral ratios listed in Table 2 were adjusted to get MAR values compatible with the Corg MAR data calculated by L. Peterson (Pers. Comm.). Comparison of sediment trap for carbonate plankton (Klaas and Archer, 2002) and diatoms (Thunell et al., 2007), showed that the Corg/mineral ratio of diatoms is approximately six times that of carbonate plankton. Variations in the values (Table 2, Supplementary material) take account of the higher dissolution of $\mathrm{CaCO}_{3}$ during the $\mathrm{BA}$, PB and Late Holocene (Mertens et al., 2009a), and of the contribution of diatoms during the Holocene, despite quasi absence of opal in the sediment during this interval (Fig. 2). Though this model is only indicative, the results are consistent with biomarker data of Dahl et al. (2004) showing a change in OM sources in the middle of the YD (Fig. 5). If organic-walled organisms contribute only ca $20 \%$ of the OM during the YD, they could account for approximately half the $\mathrm{OM}$ in sediments of the BA and $2 / 3$ for the PB (Fig. 5). During the Holocene, organic walled organisms could represent up to $80 \%$ of the OM (Fig. 5).

In high productivity marine settings such as in the Cariaco Basin, Santa Barbara Basin or Saanish Inlet, diatoms flourish in surface waters and the sediment is enriched in OM and in diatom frustules (Johnson and Grimm, 2001). Diatoms have been shown to play an important role in the quantitative and qualitative export of organic carbon to the sediment (Goutx et al., 2007; Ragueneau et al., 2000). It is therefore tempting to consider that the OM deposited in high productivity environments mainly derives from diatoms. The present study of the sediments of the Cariaco Basin however shows that the contribution of OM derived from organic-walled organisms is far from negligible and could represent more than $50 \%$ of the $\mathrm{OM}$, despite abundant presence of diatoms in surface waters. Such conclusion is consistent with the observation of a decoupling between surface primary productivity and organic carbon flux in the Cariaco Basin (Thunell et al., 2007). This decoupling demonstrates that export of $\mathrm{OM}$ is not exclusively associated to the blooming of diatoms and implies that other organisms contribute to the flux of OM to the sediment. This conclusion is also supported by numerous studies that have shown that marine snow often contains organic particles of different origins associated to opal (Alldredge et al., 1998; Goutx et al., 2007; Kovac et al., 
2005). The close correlation observed between Corg and opal settling flux in the Cariaco Basin (Thunnel et al., 2007) is not incompatible with a multiple origin of the OM and could simply indicate that $\mathrm{OM}$ of diverse origin agglomerated with diatoms prior to settling in the water column. In the case of the Cariaco Basin, the contribution from organic-walled OM finally appears as the controlling factor of the TOC content of the sediment. While diatoms are important to quantitatively export organic carbon and have an important role in the carbon cycle (Ragueneau et al., 2000), organic-walled organisms appear determinant in the formation of (very) organic-rich sediments and therefore in the formation of future petroleum source rocks. The formation of organic-rich sediment is now recognized as resulting from a subtle balance between primary productivity, OM preservation and dilution by mineral phases (Tyson, 2005). The sediments of the Cariaco Basin, an apparently simple system with high surface productivity and an anoxic water column, illustrate the subtlety of this balance, emphasizing the importance of the nature of surface producers. Organic-walled phytoplankton was prominent during the Proterozoic and most of the Phanerozoic; the development of phytoplankton with mineralized tissues is a "modern" feature, in particular since the major rise of diatoms during the Tertiary (Katz et al., 2004; Knoll et al., 2007). This also explains the frequent observation that recent organic-rich sediments from high productivity settings are not as OM-rich as ancient black-shales, pointing that modern conditions are not very good analogues for ancient OM accumulations (Tyson, 1995, 2005).

\section{Acknowledgements}

We wish to thank the ODP program for providing sediment samples from core 1002 as well as the IMAGES program and crew of the R/V Marion Dufresne. Financial support for this study was provided by the project "Enfouissement organique dans le Bassin de Cariaco : contrôles climatique et diagénétique" through the French national EVE-CYBER-LEFE program (INSU-CNRS). Larry Peterson is greatly acknowledged for providing MAR data from core PL07-39PC. J.R. Disnar, P. Martinez and A.-Y. Huc are acknowledged for their constructive comments on the manuscript.

\section{Appendix A. Supplementary material}

There is material, supplementary to this article, associated to the electronic version on doi:10.1016/j.crte.2011.04.001. 


\section{References}

Alldredge, A.L., Passow, U., Haddock, H.D., 1998. The characteristics and transparent exopolymer particle (TEP) content of marine snow formed from thecate dinoflagellates. J. Plankton Res. 20, 393-406.

Aycard, M., 2004. Géochimie des sédiments du bassin de Cariaco (Venezuela) dans le contexte de la dernière transition glaciaire-interglaciaire. Processus de sédimentation et préservation de la matière organique. Lille 1 University, 192 p.

Clayton, T., Pearce, R.B., Peterson, L.C., 1999. Indirect climatic control of the clay mineral composition of Quaternary sediments from the Cariaco basin, northern Venezuela (ODP Site 1002). Mar. Geol. 161, 191-206.

Combaz, A., Pelet, R., 1978. ORGON II Atlantique Nord-Est Brésil. Centre National de la Recherche Scientifique Publication, Paris, 392 p.

Dahl, K.A., Repeta, D.J., Goericke, R., 2004. Reconstructing the phytoplankton community of the Cariaco Basin during the Younger Dryas cold event using chlorin steryl esters. Paleoceanography 19, PA1006.

Daumas, R., Laborde, P., Paul, R., Romano, J.C., Sautriot, D., 1978. Les mécanismes de transformation de la matière organique en Atlantique intertropical. Étude de la minéralisation et de la diagenèse dans les sédiments superficiels. In: Combaz A., Pelet R. (Eds.), ORGON II Atlantique - N.-E. Brésil. CNRS, Paris, pp. 43-88.

Espitalié, J., Deroo, G., Marquis, F., 1986. La pyrolyse Rock-Eval et ses applications, troisième partie. Rev. Inst. Fr. Petr. 41, 73-89.

Ferraz-Reyes, E. 1983. Estudio del fitoplancton en la Cuenca Tuy-Cariaco, Venezuela. Bol. Inst. Oceanogr. Venezuela, Univ. Oriente 22, 111-124.

Goni, M.A., Aceves, H.L., Thunell, R.C., Tappa, E., Black, D., Astor, Y., Varela, R., MullerKarger, F., 2003. Biogenic fluxes in the Cariaco Basin: a combined study of sinking particulates and underlying sediments. Deep Sea Res. Part I 50, 781-807.

Goutx, M., Wakeham, S.G., Lee, C., Duflos, M., Guigue, C., Liu, Z., Moriceau, B., Sempéré, R., Tedetti, M., Xue, J., 2007. Composition and degradation of marine particles with different settling velocities in the northwestern Mediterranean Sea. Limnol. Oceanogr. 52, 1645-1664. Haug, G.H., Hughen, K.A., Sigman, D.M., Peterson, L.C., Rohl, U., 2001. Southward migration of the intertropical convergence zone through the Holocene. Science 293, 1304 1308 .

Head, M.J., 1996. Modern dinoflagellate cysts and their biological affinities. In: Jansonius, J., McGregor, D.C. (Eds.), Palynology: Principles and Applications. AASP Foundation, 
Publishers Press, Salt Lake City, pp. 1197-1248.

Hughen, K.A., Overpeck, J.T., Peterson, L.C., Anderson, R.F., 1996a. The nature of varved sedimentation in the Cariaco Basin, Venezuela, and its paleoclimatic significance. In: Kemp, A.E.S. (Ed.), Palaeoclimatology and palaeoceanography from laminated sediments. Geol. Soc. Spec. Pub, 116. pp. 171-183.

Hughen, K.A., Overpeck, J.T., Peterson, L.C., Trumbore, S., 1996b. Rapid climate changes in the tropical Atlantic region during the last deglaciation. Nature 380, 51-54.

Hughen, K.A., Overpeck, J.T., Lehman, S.J., Kashgarian, M., Southon, J.R., 1998. A new $14 \mathrm{C}$ calibration data set for the last deglaciation based on marine varves. Radiocarbon 40 , 483-494.

Hughen, K.A., Southon, J.R., Lehman, S.J., Overpeck, J.T., 2000. Synchronous radiocarbon and climate shifts during the last deglaciation. Science 290, 1951-1954.

Hughen, K.A., Eglinton, T.I., Xu, L., Makou, M., 2004a. Abrupt tropical vegetation response to rapid climate changes. Science 304, 1955- 1959.

Hughen, K.A., Southon, J.R., Bertrand, C.J.H., Frantz, B., Zermeno, P., 2004b. Cariaco Basin calibration update: Revisions to calendar and 14C chronologies for core PL07-58PC. Radiocarbon 46, 1161-1187.

Hughen, K., Southon, J., Lehman, S., Bertrand, C., Turnbull, J., 2006. Marine-derived 14C calibration and activity record for the past 50,000 years updated from the Cariaco Basin. Quat. Sci. Rev. 25, 3216-3227.

Johnson, K.M., Grimm, K.A., 2001. Opal and organic carbon in laminated diatomaceous sediments: Saanich Inlet. Santa Barbara Basin and the Miocene Monterey Formation. Mar. Geol. 174, 159-175.

Katz, M.E., Finkel, Z.V., Grzebyk, D., Knoll, A.H., Falkowski, P.G., 2004. Evolutionary trajectories and biogeochemical impacts of marine eukaryotic phytoplankton. Annu. Rev. Ecol. Evol. Sys. 35, 523-556.

Klaas, C., Archer, D.E., 2002. Association of sinking organic matter with various types of mineral ballast in the deep sea: implications for the rain ratio. Glob. Biogeochem. Cycles 16, 1116.

Knoll, A.H., Summons, R.E., Waldbauer, J., Zumberge, J., 2007. The geological succession of primary producers in the oceans. In: Falkowski, P., Knoll, A.H. (Eds.), The Evolution of Primary Producers in the Sea. Elsevier Academic Press, London, pp. 133-163.

Kovac, N., Mozetic, P., Trichet, J., Défarge, C., 2005. Phytoplankton composition and organic matter organization of mucous aggregates by means of light and cryo-scanning 
electron microscopy. Mar. Biol. 147, 261-271.

Laj, C., Shipboard Scientific Party, 2004. MD132/IMAGES XI, PICASSO cruise report, Institut Polaire Francais Paul-Émile Victor (IPEV), Les rapports de campagnes à la mer, 76 p. Lane-Serff, G.F., Pearce, R.B., 2009. Modeling hydrography and marine sedimentation in the Cariaco Basin since the Last Glacial Maximum. J. Geophys. Res. 114, C04003.

Lyons, T.W., Werne, J.P., Hollander, D.J., Murray, R.W., 2003. Contrasting sulfur geochemistry and $\mathrm{Fe} / \mathrm{Al}$ and $\mathrm{Mo} / \mathrm{Al}$ ratios across the last oxicto- anoxic transition in the Cariaco Basin. Venezuela. Chem. Geol. 195, 131-157.

Mertens, K.N., Lynn, M., Aycard, M., Lin, H.-L., Louwye, S., 2009a. Coccolithophores as paleoecological indicators for shift of the ITCZ in the Cariaco Basin. J. Quat. Sci. 24, 159174.

Mertens, K.N., Gonzalez, C., Delusina, I., Louwye, S., 2009b. 30000 years of productivity and salinity variations in the Late Quaternary Cariaco Basin revealed by dinoflagellate cysts. Boreas 38, 647-662.

Müller-Karger, F., Varela, R., Thunell, R., Scranton, M., Bohrer, R., Taylor, G., Capelo, J., Astor, Y., Tappa, E., Ho, T.Y., Walsh, J.J., 2001. Annual cycle of primary production in the Cariaco Basin: Response to upwelling and implications for vertical export. J. Geophys. Res. Oceans 106, 4527-4542.

Müller-Karger, F.E., Varela, R., Thunell, R.C., Scranton, M.I., Taylor, G.T., Astor, Y., Benitez-Nelson, C.R., Lorenzoni, L., Tappa, E., Goni, M.A., Rueda, D., Hu, C., 2010. The Cariaco Basin: CARIACO Oceanographic Time Series. In: Liu, K.K., Atkinson, L. (Eds.), Carbon and Nutrient Fluxes in Continental Margins: A Global Synthesis. JGOFS Continental Margins Task Team, Springer-Verlag, Berlin, pp. 454-464.

Paillard, D., Labeyrie, L., Yiou, P., 1996. Macintosh program performs timeseries analysis. EOS 77, 379.

Peterson, L.C., Haug, G.H., 2006. Variability in the mean latitude of the Atlantic Intertropical Convergence Zone as recorded by riverine input of sediments to the Cariaco Basin (Venezuela). Palaeogeogr. Palaeoclimatol. Palaeoecol. 234, 97-113.

Peterson, L.C., Overpeck, J.T., Kipp, N.G., Imbrie, J., 1991. A high-resolution Late Quaternary upwelling record from the anoxic Cariaco basin, Venezuela. Paleoceanography 6, 99-119.

Peterson, L.C., Overpeck, J.T., Murray, D.W., 1995. Anoxic basin records detailed climate history. JOI/USSAC Newslett. 8, 10-13.

Peterson, L.C., Haug, G.H., Hughen, K.A., Rohl, U., 2000. Rapid changes in the hydrologic 
cycle of the tropical Atlantic during the Last Glacial. Science 290, 1947-1951.

Piper, D.Z., Dean, W.E., 2002. Trace-element deposition in the Cariaco Basin, Venezuela shelf, under sulfate-reducing conditions. A history of the local hydrography and global climate, $20 \mathrm{Ka}$ to the Present. USGS Prof. Paper 1670, $41 \mathrm{p}$.

Ragueneau, O., Tréguer, P., Leynaert, A., Anderson, R.F., Brzezinski, M.A., DeMaster, D.J., Dugdale, R.C., Dymond, J., Fischer, G., François, R., Heinze, C., Maier-Reimer, E., MartinJézéquel, V., Nelson, D.M., Quéguiner, B., 2000. A review of the Si cycle in the modern ocean: recent progress and missing gaps in the application of biogenic opal as a paleoproductivity proxy. Glob. Planet. Change 26, 317-365.

Richards, F.A., 1975. The Cariaco basin (trench). Oceanogr. Mar. Biol. Ann. Rev. 13, 11-67. Shipboard Scientific Party, 1997. Site 1002. In: Sigurdsson, H., Leckie, R.M., Acton, G.D., et, al. (Eds.), Proceedings of the ocean drilling program, initial reports, 165. pp. 359-373.

Thunell, R.C., Varela, R., Llano, M., Collister, J., Müller-Karger, F., Bohrer, R., 2000. Organic carbon fluxes, degradation, and accumulation in an anoxic basin: Sediment trap results from the Cariaco Basin. Limnol. Oceanogr. 45, 300-308.

Thunell, R., Benitez-Nelson, C., Varela, R., Astor, Y., Müller-Karger, F., 2007. Particulate organic carbon fluxes along upwelling-dominated continental margins: Rates and mechanisms. Glob. Biogeochem. Cycles 21, GB1022.

Tyson, R.V., 1995. Sedimentary organic matter. Chapman \& Hall, London, 616 p.

Tyson, R.V., 2005. The “productivity versus preservation”' controversy: cause, flaws, and resolution. In: Harris, N.B. (Ed.), The deposition of organic carbon-rich sediments: models, mechanisms and consequences. SEPM Spec. Pub., 82. Tulsa, Oklahoma, pp. 17-33.

Wakeham, S.G., 1990. Algal and bacterial hydrocarbons in particulate matter and interfacial sediment of the Cariaco Trench. Geochim. Cosmochim. Acta 54, 1325-1336.

Wedepohl, K.H., 1991. The composition of the upper Earth's crust and the natural cycles of selected metals. In: Merian, E. (Ed.), Metals and their compounds in the Environment. VCHVerlagsgesellschaft, Weinheim, pp. 3-17.

Werne, J.P., Hollander, D.J., Lyons, T.W., Peterson, L.C., 2000. Climate induced variations in productivity and planktonic ecosystem structure from the Younger Dryas to Holocene in the Cariaco Basin. Venezuela. Paleoceanography 15, 19-29.

Werne, J.P., Lyons, T.W., Hollander, D.J., Formolo, M.J., Sinninghe Damsté, J.S., 2003. Reduced sulfur in euxinic sediments of the Cariaco Basin: sulfur isotope constraints on organic sulfur formation. Chem. Geol. 195, 159-179.

Zonneveld, K.A.F., Bockelmann, F., Holzwarth, U., 2007. Selective preservation of organic- 
walled dinoflagellate cysts as a tool to quantify past net production and bottom water oxygen concentrations. Mar. Geol. 237, 109-126. 


\section{Figure Captions}

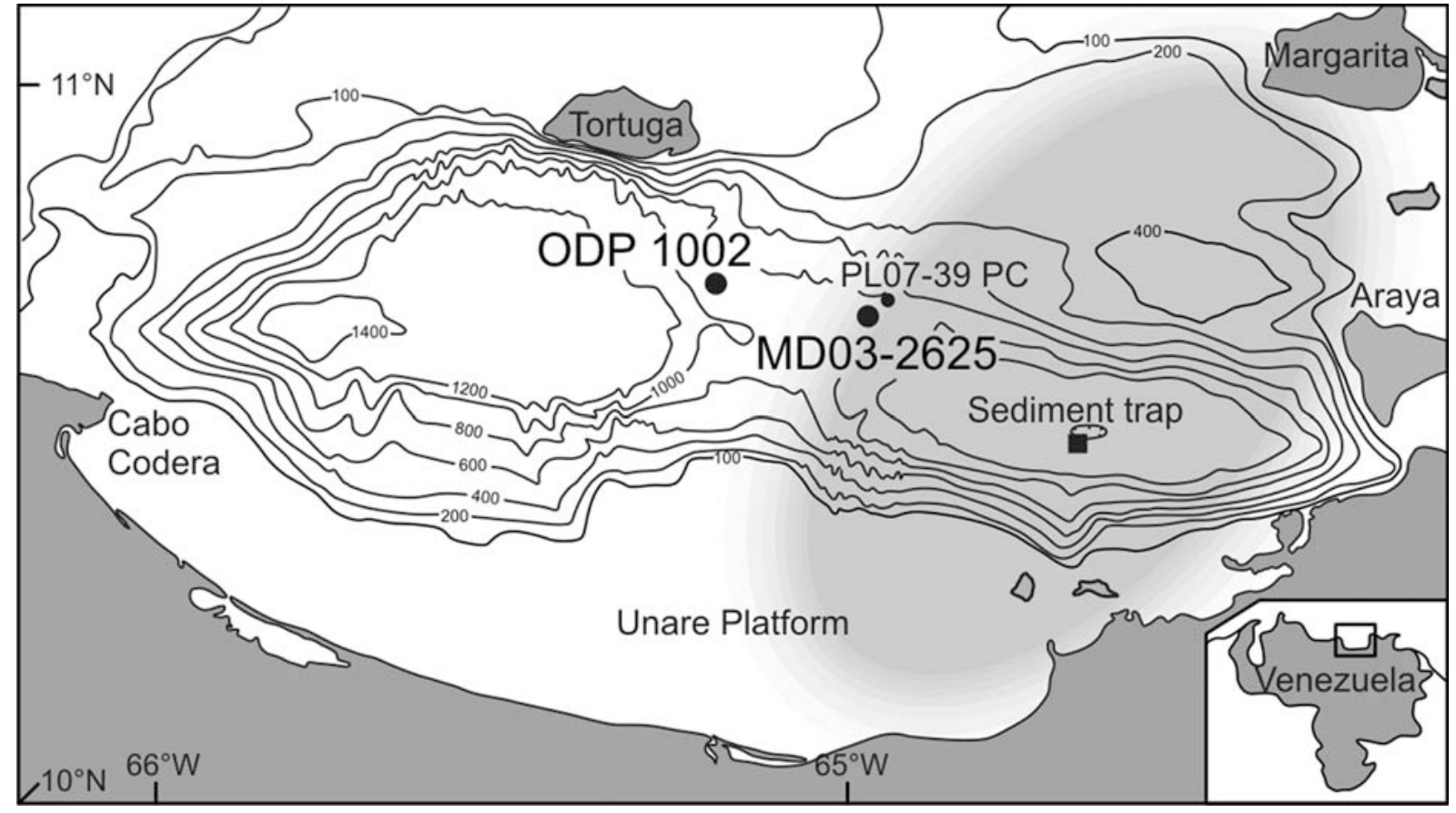

Fig. 1. Location map of the Cariaco Basin, studied cores and sediment trap discussed in the text. The grey area corresponds to present-day average position of the upwelling cell.

Fig. 1. Carte de localisation du bassin de Cariaco, des carottes étudiées et des pièges à sédiments discutés dans le texte. La zone en gris correspond à la position moyenne actuelle de la cellule d'upwelling. Adapted from Müller-Karger et al., 2010. 

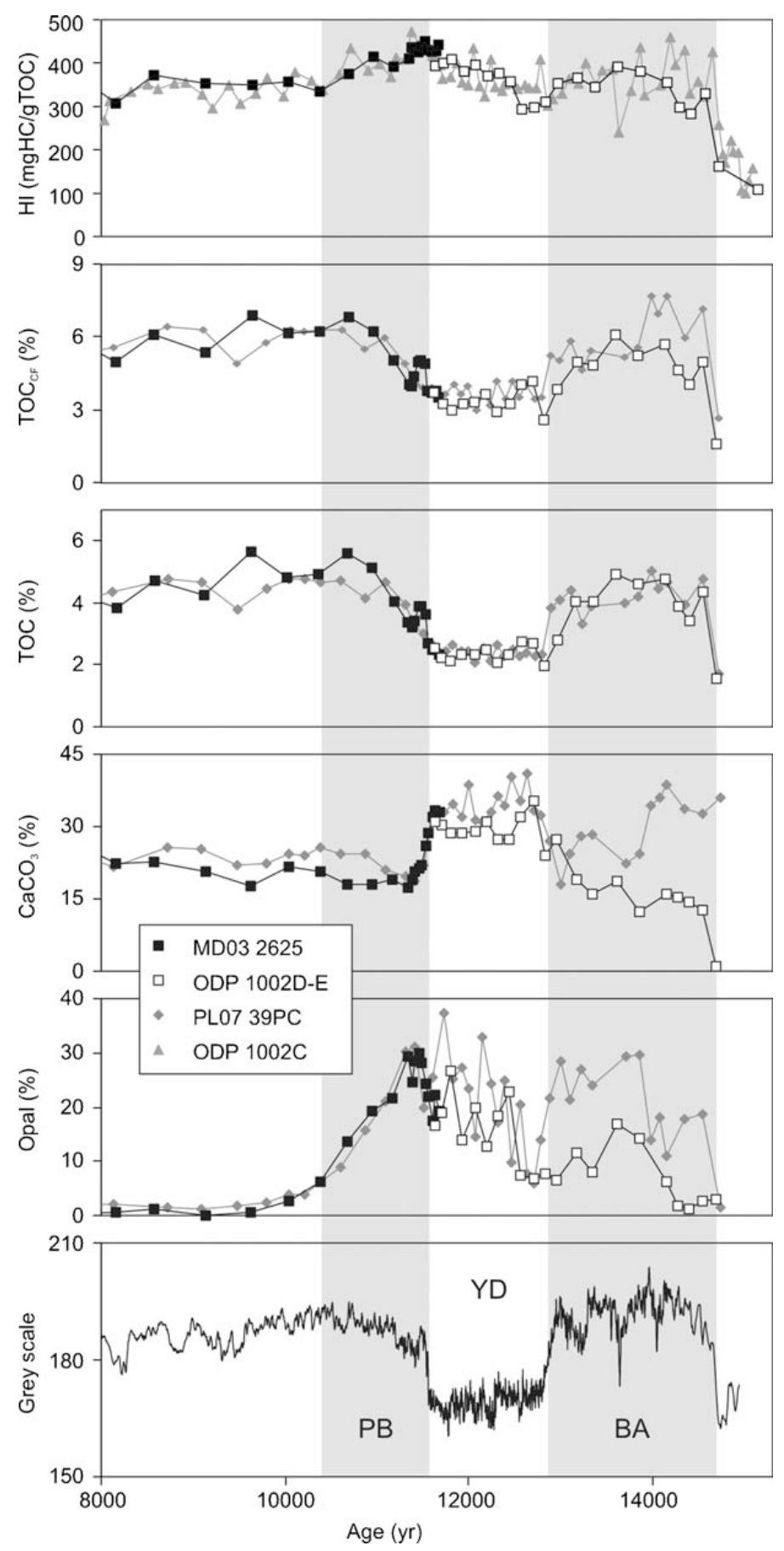

Fig. 2. Temporal variations of Cariaco sediment color and geochemical parameters. Sediment color from Hughen et al. (1996b) (core PL07-56PC). Squares: this study; diamonds: Piper and Dean, 2002 and L. Peterson Pers. Comm., 2009; triangles: Aycard (2004). PB: Preboreal, YD: Younger Dryas, BA: Bølling Allerød.

Fig. 2. Variations temporelles de la couleur des sédiments de Cariaco et des paramètres géochimiques. Couleur du sédiment d'après Hughen et al. (1996b) (carotte PL07-56PC). Carrés : cette étude; losanges : Piper and Dean, 2002 et L. Peterson Comm. Pers., 2009 ; triangles : Aycard (2004). PB : Préboréal, YD : Dryas récent, BA : Bølling Allerød. 

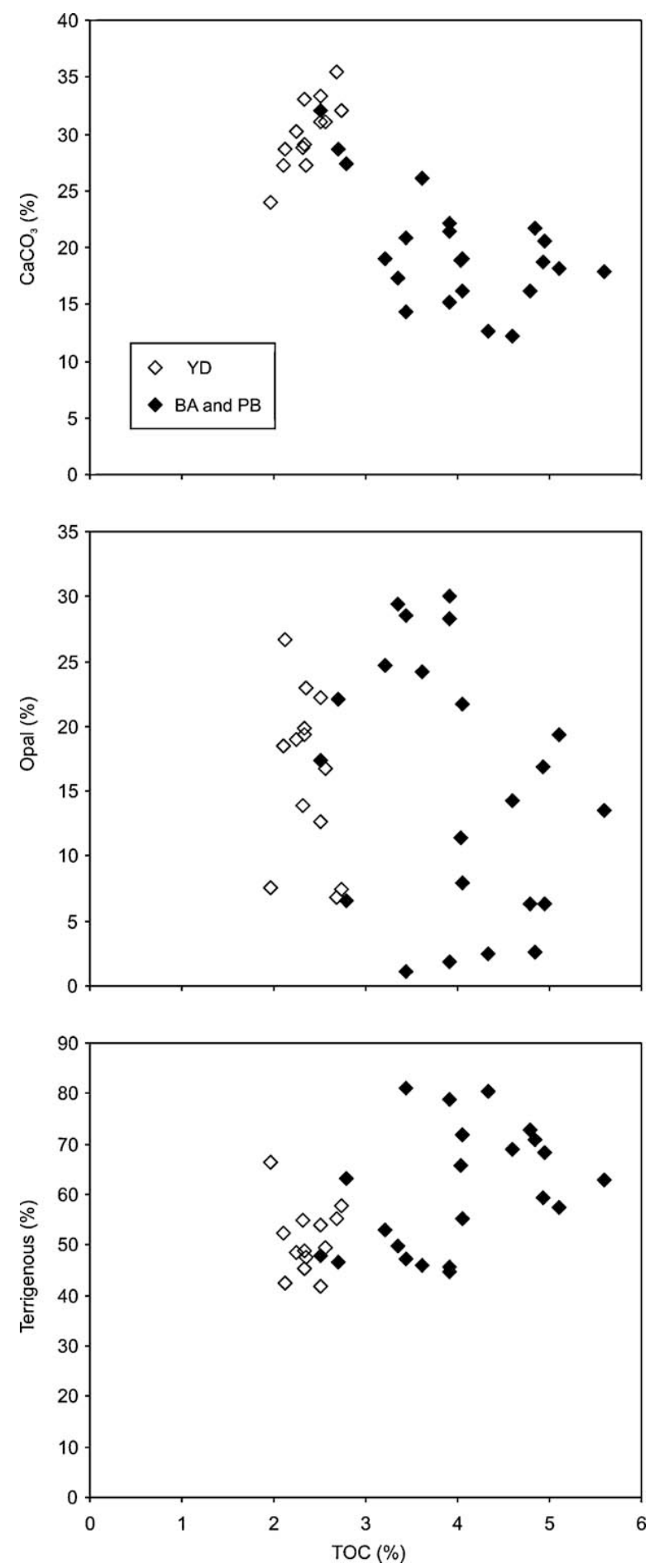

Fig. 3. Cross plot of the total organic carbon content (TOC) and the different mineral fractions of Cariaco sediments. Data only covering the BA to PB interval.

Fig. 3. Graphiques de corrélation du contenu en carbone organique (COT) et des différentes fractions minérales du sédiment de Cariaco. Les données ne montrent que la période allant du BA au PB. 

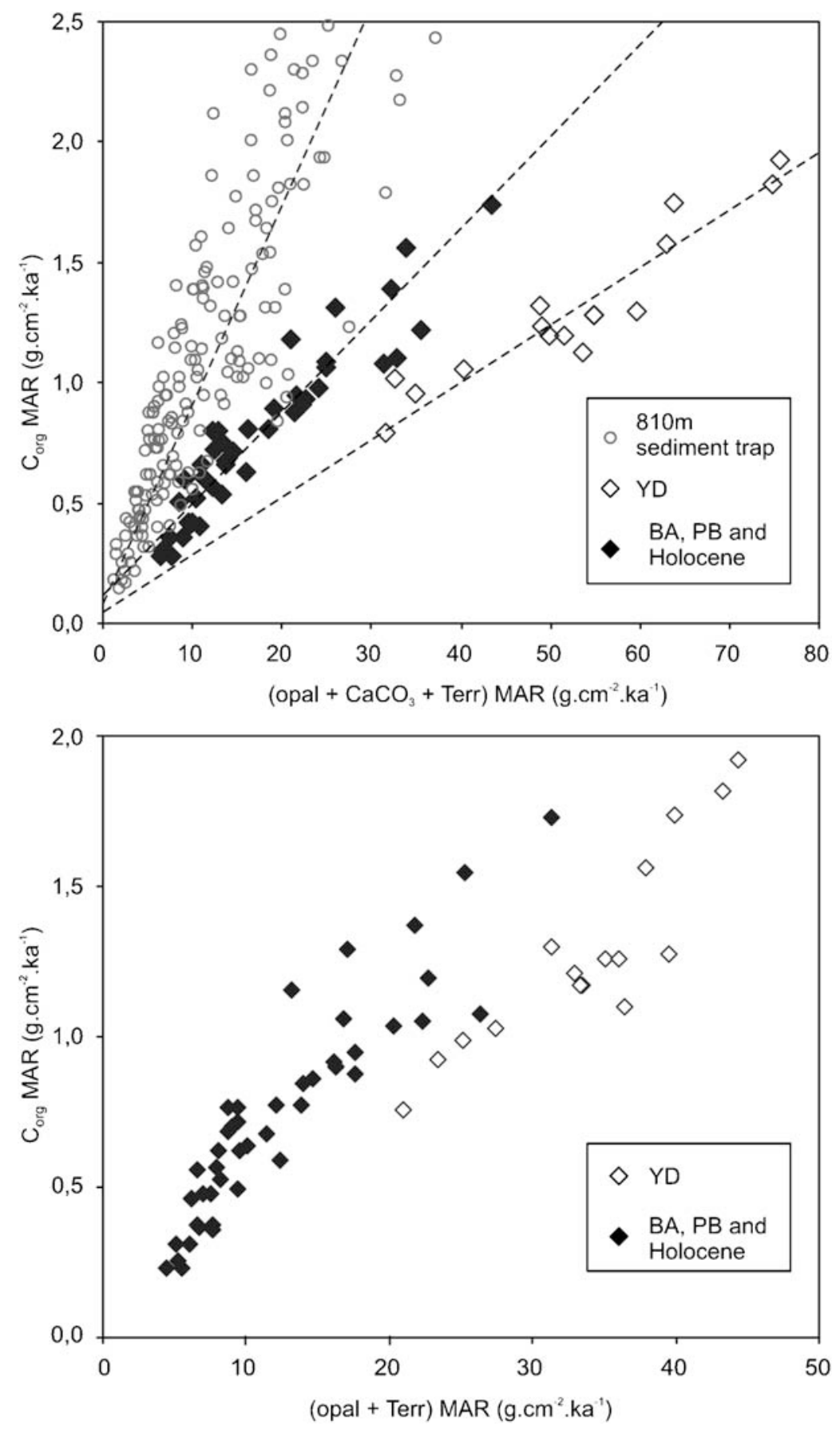

Fig. 4. A. Cross plot of organic carbon MAR versus MAR of the mineral fraction of Cariaco sediments. B. Same data without $\mathrm{CaCO}_{3}$ MAR. Data from core PL07-39PC covering the totality of the last 14,7 ka (L. Peterson, Pers. Comm., 2009). 810m sediment trap data from Thunell et al. (2007).

Fig. 4. A. Taux d'accumulation massique (MAR) du carbone organique en fonction de celui de la fraction minérale. B. Mêmes données sans les carbonates. Les données proviennent de la carotte PL07-39PC et couvrent la totalité des derniers 14,7 ka (L. Peterson, Comm. Pers., 2009). Piège à sédiment à $810 \mathrm{~m}$ d'après Thunell et al. (2007). 

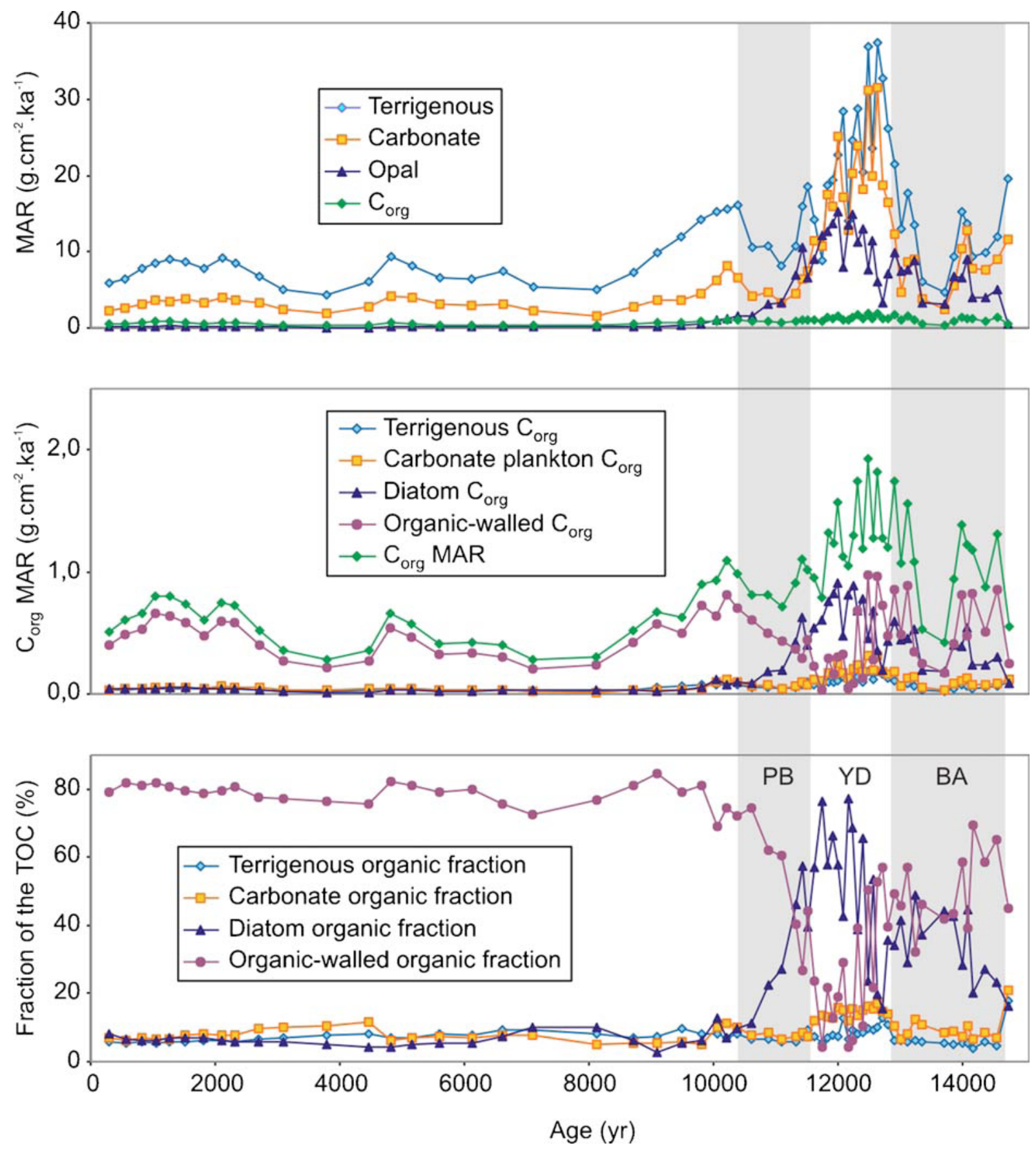

Fig. 5. A. MAR of the different sediment components (L. Peterson, Pers. Comm., 2009). B. Computed Corg MAR of the different sources of organic carbon. C. Computed fraction of the TOC for the different sources of organic carbon.

Fig. 5. A. Taux d'accumulation massique (MAR) des différentes fractions du sédiment (L. Peterson, Comm. Pers., 2009). B. Corg MAR calculé pour les différentes sources de carbone organique. C. Fraction du TOC calculée pour les différentes sources de carbone organique. 


\section{Table 1}

Average mass accumulation rates (MAR, in $\mathrm{g} . \mathrm{cm}^{-2} \cdot \mathrm{ka}^{-1}$ ) of the different components of Cariaco sediment in core PL07-39PC (L. Peterson, 2009 Pers. comm.).

Tableau 1

Taux d'accumulation massique moyens (MAR, en $\mathrm{g} \cdot \mathrm{cm}^{-2} \cdot \mathrm{ka}^{-1}$ ) des différentes fractions du sédiment de Cariaco dans la carotte PL07-39PC (L. Peterson, 2009 Comm. Pers.).

\begin{tabular}{lccll}
\hline & $\mathrm{CaCO}_{3}$ MAR & Opal MAR & Corg MAR & Terr MAR \\
\hline PB & 6.27 & 4.49 & 0.93 & 13.58 \\
YD & 19.93 & 10.70 & 1.34 & 24.45 \\
BA & 7.83 & 6.28 & 1.11 & 12.16 \\
MAR ratios & & & & \\
YD/BA & 2.54 & 1.70 & 1.21 & 2.01 \\
YD/PB & 3.18 & 2.38 & 1.44 & 1.80 \\
\hline
\end{tabular}

\section{Table 2}

Corg/mineral ratio of the different sources of organic carbon used for modelisation (Full detail in Supplementary material).

Tableau 2

Rapport Corg/minéral des différentes sources organiques utilisées pour la modélisation

\begin{tabular}{llll}
\hline & Carbonate plankton & Diatoms & Terrestrial flux \\
\hline $\mathrm{C}_{\text {org }} /$ mineral & $0.010-0.015$ & $0.060-0.200$ & 0.005 \\
\hline
\end{tabular}

